\title{
New two-layer Ruddlesden-Popper cathode materials for protonic ceramics fuel cells
}

\author{
Yihan LING*, Tianming GUO, Yangyang GUO, Yang YANG, \\ Yunfeng TIAN, Xinxin WANG, Xuemei OU, Peizhong FENG
}

School of Materials Science and Physics, China University of Mining and Technology, Xuzhou 221116, China

Received: February 1, 2021; Revised: April 15, 2021; Accepted: April 27, 2021

(C) The Author(s) 2021.

\begin{abstract}
New two-layer Ruddlesden-Popper (RP) oxide $\mathrm{La}_{0.25} \mathrm{Sr}_{2.75} \mathrm{FeNiO}_{7-\delta}$ (LSFN) in the combination of $\mathrm{Sr}_{3} \mathrm{Fe}_{2} \mathrm{O}_{7-\delta}$ and $\mathrm{La}_{3} \mathrm{Ni}_{2} \mathrm{O}_{7-\delta}$ was successfully synthesized and studied as the potential active single-phase and composite cathode for protonic ceramics fuel cells (PCFCs). LSFN with the tetragonal symmetrical structure $(I 4 / \mathrm{mmm})$ is confirmed, and the co-existence of $\mathrm{Fe}^{3+} / \mathrm{Fe}^{4+}$ and $\mathrm{Ni}^{3+} / \mathrm{Ni}^{2+}$ couples is demonstrated by X-ray photoelectron spectrometer (XPS) analysis. The LSFN conductivity is apparently enhanced after $\mathrm{Ni}$ doping in Fe-site, and nearly three times those of $\mathrm{Sr}_{3} \mathrm{Fe}_{2} \mathrm{O}_{7-\delta}$, which is directly related to the carrier concentration and conductor mechanism. Importantly, anode supported PCFCs using LSFN-BaZr $0{ }_{0.1} \mathrm{Ce}_{0.7} \mathrm{Y}_{0.2} \mathrm{O}_{3-\delta}$ (LSFN-BZCY) composite cathode achieved high power density $\left(426 \mathrm{~mW} \cdot \mathrm{cm}^{-2}\right.$ at $\left.650{ }^{\circ} \mathrm{C}\right)$ and low electrode interface polarization resistance $\left(0.26 \Omega \cdot \mathrm{cm}^{2}\right)$. Besides, distribution of relaxation time (DRT) function technology was further used to analyse the electrode polarization processes. The observed three peaks (P1, P2, and P3) separated by DRT shifted to the high frequency region with the decreasing temperature, suggesting that the charge transfer at the electrode-electrolyte interfaces becomes more difficult at reduced temperatures. Preliminary results demonstrate that new two-layer RP phase LSFN can be a promising cathode candidate for PCFCs.
\end{abstract}

Keywords: protonic ceramics fuel cells (PCFCs); Ruddlesden-Popper (RP) phase; single-phase cathode; distribution of relaxation time (DRT) function; charge transfer

\section{Introduction}

Protonic ceramics fuel cells (PCFCs) possess several advantages of high proton conductivity electrolytes with low activation energy and high fuel efficiency, being more attractive at reduced operating temperatures [1-4]. However, as the temperature reduced, the corresponding challenge for the oxygen reduction

\footnotetext{
* Corresponding author.

E-mail: lyhyy@cumt.edu.cn
}

reaction is the reduced cathodic catalytic activity, causing the large electrode polarization loss and fast degradation of cell performance [5-7]. Therefore, great efforts have been devoted to developing new cathode materials and modifying high performance conventional cathode materials that can own high catalytic activity at reduced temperatures.

New cathodes with mixed conductivity based on simple perovskite (doped $\mathrm{LaCoO}_{3}, \mathrm{BaCoO}_{3}$, and $\mathrm{LaFeO}_{3}$ ) have been extensively studied [8-13]. Considering high oxygen-ion defect concentration, oxygen diffusion 
anisotropy, and cation ordered-structure, several recent studies have highlighted the promising of the Ruddlesden-Popper (RP) series, $\mathrm{A}_{n+1} \mathrm{BnO}_{3 n+1}$, for cathode application, where the special sandwich structure consists of $n \mathrm{ABO}_{3}$ perovskite and two $\mathrm{AO}$ rock salt layers [14-19]. The $\mathrm{Sr}_{3} \mathrm{Fe}_{2} \mathrm{O}_{7-\delta}$-based systems, belonging to the $n=2$ series, have been widely investigated owing to their high oxygen deficiency, excellent water-intercalation property, and prominent catalytic activity [20-22]. The partial substitution of $\mathrm{Ni}$ for $\mathrm{Fe}$ in $\mathrm{Sr}_{3} \mathrm{Fe}_{2} \mathrm{O}_{7-\delta}$ can increase the electrical conductivity and the oxygen permeability without structural transformation [23,24]. In our previous works, the introduction of $\mathrm{La}$ into $\mathrm{Sr}$-site forming $\mathrm{La}_{x} \mathrm{Sr}_{3-x} \mathrm{Fe}_{2} \mathrm{O}_{7-\delta}$ can enhance thermo-chemical stability as well as large oxygen deficiency $[25,26]$. Moreover, another RP phase, $\mathrm{La}_{3} \mathrm{Ni}_{2} \mathrm{O}_{7-\delta}(n=2)$, showed large electrical conductivity, acceptable stability, and similar thermal expansion coefficient to electrolytes [27-29]. Therefore, in this work, we combine the advantages of $\mathrm{Sr}_{3} \mathrm{Fe}_{2} \mathrm{O}_{7-\delta}$ and $\mathrm{La}_{3} \mathrm{Ni}_{2} \mathrm{O}_{7-\delta} \mathrm{RP}$ phase oxides thanks to their similar ionic radii and chemical properties, expecting to enhance the conductivity and electrochemical activity without structural transformation. Here, $\mathrm{La}_{0.25} \mathrm{Sr}_{2.75} \mathrm{FeNiO}_{7-\delta}$ (LSFN) was successfully prepared and the electrochemical performance was investigated to verify the possibility for using as cathode material for PCFCs. In addition, LSFN incorporated with $\mathrm{BaZr}_{0.1} \mathrm{Ce}_{0.7} \mathrm{Y}_{0.2} \mathrm{O}_{3-\delta}$ (BZCY) to form a composite cathode for PCFCs was also examined. The polarization processes for PCFCs under working condition were detailly analyzed by the distribution of relaxation time (DRT) method.

\section{Experimental}

LSFN, NiO-BZCY, and BZCY powders were synthesized by ethylenediamine tetraacetic acid (EDTA)-citric acid combustion method, and the primary powders were calcined at 1200, 1100, and $1100{ }^{\circ} \mathrm{C}$ for $3 \mathrm{~h}$, respectively [30]. X-ray diffraction (XRD) was used to perform all prepared powders as well as LSFN-BZCY (1:1 wt\%) mixtures calcined at different temperatures. X-ray photoelectron spectrometer (XPS) was used to analyze the elemental chemical state of LSFN, and then the conductivity measurement by H.P. multimeter using the standard DC four-probe technique was investigated from 800 to $300{ }^{\circ} \mathrm{C}$ in air.

Anode supported PCFCs with LSFN single-phase and composite cathode was used to investigate the electrochemical performance. The NiO-BZCY-starch/ NiO-BZCY/BZCY anode supported half cells were prepared by the dry pressing and then sintering at $1400{ }^{\circ} \mathrm{C}$ for $3 \mathrm{~h}$. Finally, LSFN and LSFN-BZCY ( 7:3 wt $\%$ ) cathode slurries were brushed onto BZCY electrolyte surface severally, and then calcined at $900{ }^{\circ} \mathrm{C}$ for $3 \mathrm{~h}$ in air. The effective electrode area of the single cells was $0.2 \mathrm{~cm}^{2}$. Anode supported PCFCs were evaluated by cell-testing system with humidified $(\sim 3 \%$ $\left.\mathrm{H}_{2} \mathrm{O}\right) \mathrm{H}_{2}$ fuel at $500-650{ }^{\circ} \mathrm{C}$. The impedance spectra (Chi604E, Shanghai Chenhua) under open-current conditions were investigated with the frequency range of $0.01 \mathrm{~Hz}-100 \mathrm{kHz}$ and $\mathrm{AC}$ amplitude of $10 \mathrm{mV}$ at $500-650{ }^{\circ} \mathrm{C}$, of which the microstructure was performed using scanning electron microscopy (SEM).

\section{Results and discussion}

XRD pattern of prepared LSFN powder is presented in Fig. 1(a), which clearly shows the tetragonal symmetry defined with the space group of $I 4 / \mathrm{mmm}$ in the light of standard powder diffraction information for $\mathrm{Sr}_{3} \mathrm{Fe}_{2} \mathrm{O}_{7-\delta}$, indicating that the partial replacement of $\mathrm{Fe}$ with $\mathrm{Ni}$ can not affect the single RP phase structure [20-22]. Rietveld analysis was performed by the GSAS software and the XRD Rietveld refinement results are also given in Figs. 1(a) and 1(b) (the magnified results with $2 \theta$ of $\left.25^{\circ}-50^{\circ}\right)$, where low refinement reliability factors $\left(w_{R \mathrm{p}}=\right.$ $12.90 \%, R_{\mathrm{p}}=9.84 \%$, and $\left.\chi^{2}=2.05\right)$ were obtained. The calculated lattice parameters $a$ and $c$ based on this model are 3.8364(50) and 20.0376(93) A, respectively, and one can clearly see that two perovskite layers are sandwiched by the rock-salt layer along the $c$-axis in the typical two-layer RP phase structure as illustrated in Fig. 1(c). In addition, LSFN sample with high crystallinity and well-defined crystalline fringes was observed in Fig. 1(d), and the lattice spacing of 0.2658 $\mathrm{nm}$ corresponds to the lattice spacing of the (110) plane in the tetragonal symmetry in selected- angle diffraction in Fig. 1(b). All results together demonstrate the well maintained single RP phase structure after the combination of two RP phase oxides of $\mathrm{Sr}_{3} \mathrm{Fe}_{2} \mathrm{O}_{7-\delta}$ and $\mathrm{La}_{3} \mathrm{Ni}_{2} \mathrm{O}_{7-\delta}$.

The elemental chemical state was characterized by XPS, and La 3d, Sr 3d, Fe 2p, and Ni 2p peaks in XPS spectra for LSFN sample at room temperature are shown in Fig. 2. The peaks of binding energies of $\mathrm{La}$ 


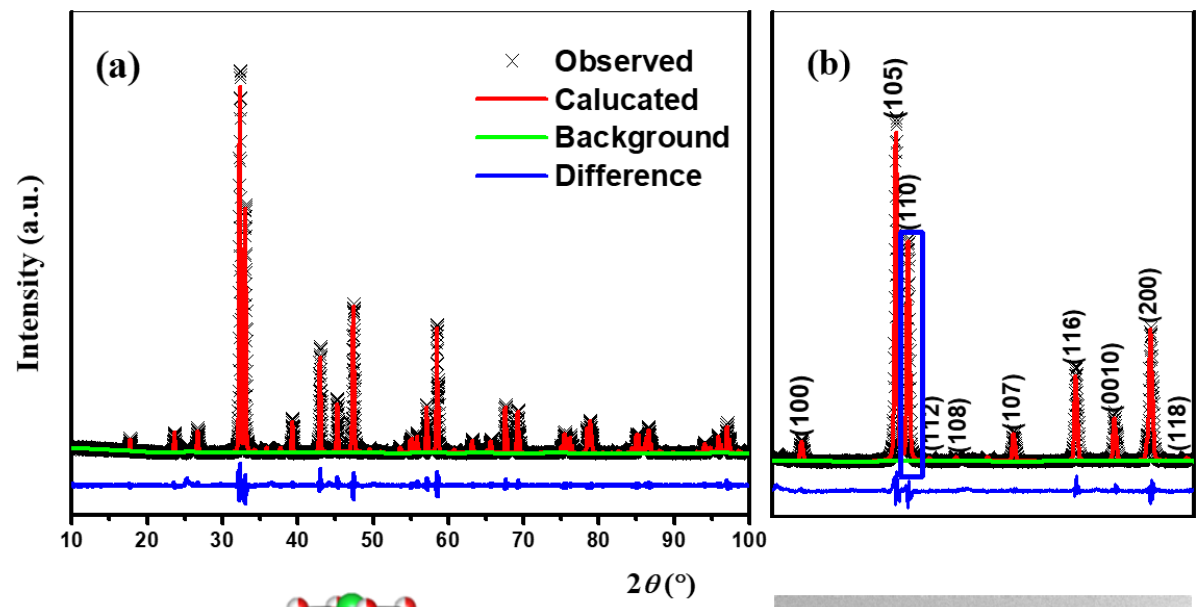

(c)

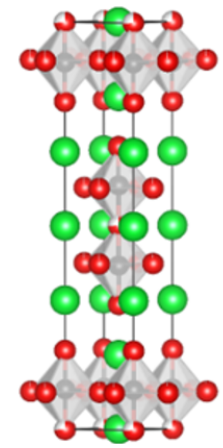

(d)

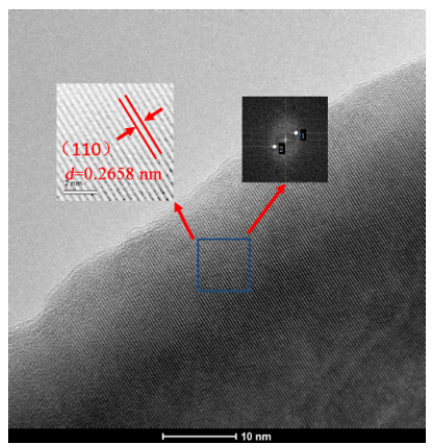

Fig. 1 (a) Rietveld refinement data for LSFN powder prepared through EDTA-citric acid combustion method, and calcined at $1200{ }^{\circ} \mathrm{C}$ for $3 \mathrm{~h}$; (b) magnified results with $2 \theta$ of $25^{\circ}-50^{\circ}$; (c) the typical two-layer RP phase structure; and (d) high-resolution TEM image of LSFN samples.
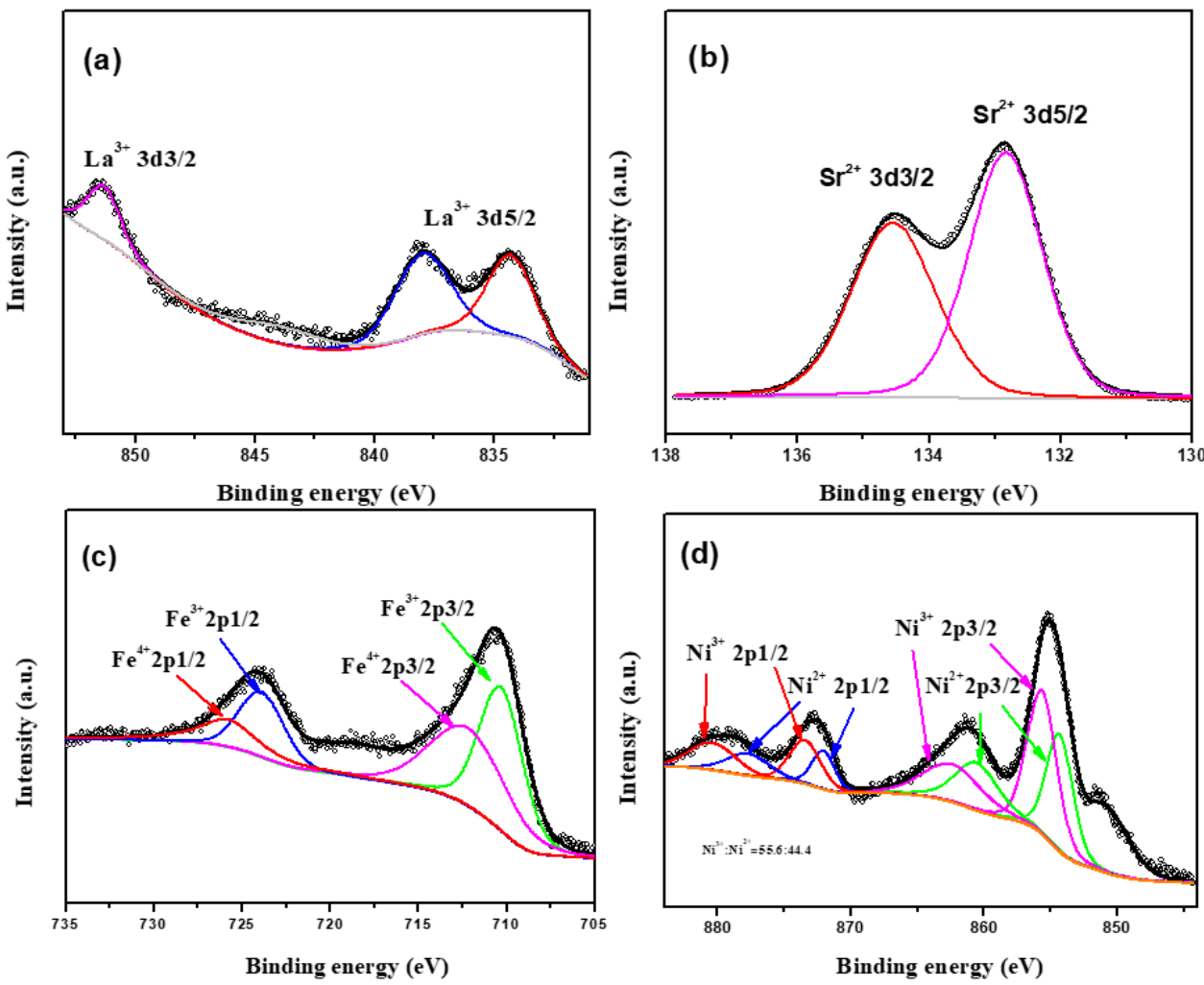

Fig. 2 XPS spectra at room temperature for (a) La 3d, (b) Sr 3d, (c) Fe 2p, and (d) Ni 2p of LSFN sample. 
$3 \mathrm{~d} 5 / 2$ (at 834.4 and $838.1 \mathrm{eV}$ ) and $\mathrm{La} 3 \mathrm{~d} 3 / 2$ (at $851.5 \mathrm{eV}$ ) represent $\mathrm{La}^{3+}$ as revealed in Fig. 2(a). Figure 2(b) proves $\mathrm{Sr}$ in LSFN sample displays a $2^{+}$valence state with the binding energies of $\mathrm{Sr} 3 \mathrm{~d} 5 / 2$ (at $132.8 \mathrm{eV}$ ) and Sr 3d 3/2 (at $134.6 \mathrm{eV}$ ). Figure 2(c) shows the Fe 2p binding energy region of LSFN sample, where the location of 710.5/724.1 eV and 712.5/725.9 eV peaks are related to the $(\mathrm{Fe} 2 \mathrm{p} 3 / 2) /(\mathrm{Fe} 2 \mathrm{p} 1 / 2)$ signals for $\mathrm{Fe}^{3+}$ and $\mathrm{Fe}^{4+}$, respectively, and the proportion of $\mathrm{Fe}^{4+} / \mathrm{Fe}^{3+}$ is about 0.898 without the peaks of $\mathrm{Fe}^{2+}[31,32]$. Figure 2(d) reports the Ni 2p XPS spectra of LSFN sample, and the $\mathrm{Ni} 2 \mathrm{p}$ peaks that envelope the $\mathrm{Ni}^{2+}$ and $\mathrm{Ni}^{3+}$ valence states are fitted. One can clearly observe the four characteristic peaks with the binding energy of $855.8,862.7,873.5$, and $880.5 \mathrm{eV}$, which related to $\mathrm{Ni}^{3+} 3 \mathrm{~d} 5 / 2$ and $\mathrm{Ni}^{3+} 3 \mathrm{~d} 3 / 2$, while the peaks of $2 \mathrm{p} 1 / 2$ at 872.1 and $877.8 \mathrm{eV}$ and $2 \mathrm{p} 3 / 2$ at 854.4 and $860.7 \mathrm{eV}$ can be attributed to $\mathrm{Ni}^{2+}$, where the proportion of $\mathrm{Ni}^{3+} / \mathrm{Ni}^{2+}$ is about 1.25 [33-35]. The XPS results conform the fact that $\mathrm{Fe}^{3+} / \mathrm{Fe}^{4+}$ and $\mathrm{Ni}^{3+} / \mathrm{Ni}^{2+}$ couples co-exist in the LSFN sample. Moreover, the conductivity of LSFN can be considered to be affected in LSFN sample as follows:

$$
\mathrm{Fe}^{4+}+\mathrm{Ni}^{2+} \leftrightarrow \mathrm{Fe}^{3+}+\mathrm{Ni}^{3+}
$$

Therefore, the introduction $\mathrm{Ni}^{3+} / \mathrm{Ni}^{2+}$ couples would be expected to enhance the conductivity and electrochemical properties of the LSFN sample.

The electrical conductivity for $\mathrm{Sr}_{3} \mathrm{Fe}_{2} \mathrm{O}_{7-\delta}$ sample increases to a peak of about $60.4 \mathrm{~S} \cdot \mathrm{cm}^{-1}$ at around $500{ }^{\circ} \mathrm{C}$, and then reduces as the temperature increases from 300 to $800{ }^{\circ} \mathrm{C}$ as shown in Fig. 3, exhibiting typical semi-conductor-like behavior [21,22]. Figure 3 also gives the electronic conductivity of LSFN sample

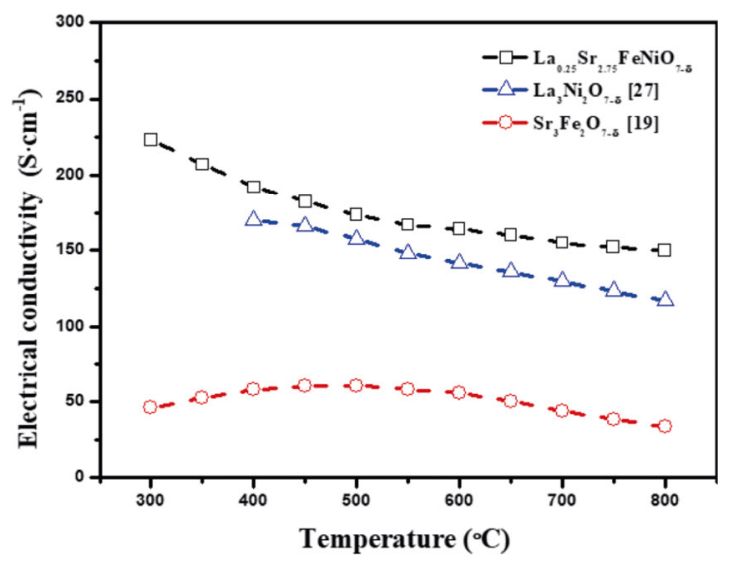

Fig. 3 Temperature dependence on conductivity for LSFN in air, and $\mathrm{Sr}_{3} \mathrm{Fe}_{2} \mathrm{O}_{7-\delta}$ and $\mathrm{La}_{3} \mathrm{Ni}_{2} \mathrm{O}_{7-\delta}$ conductivity data from Refs. [19,27]. measured at $300-800{ }^{\circ} \mathrm{C}$ in air, and LSFN sample presents typical metallic behavior as well as $\mathrm{La}_{3} \mathrm{Ni}_{2} \mathrm{O}_{7-\delta}$, of which the conductivities increase with the decrease of temperatures $\left(223 \mathrm{~S} \cdot \mathrm{cm}^{-1}\right.$ at $300{ }^{\circ} \mathrm{C}$ [29]). The charge carriers, $\mathrm{Fe}^{3+} / \mathrm{Fe}^{4+}$ and $\mathrm{Ni}^{3+} / \mathrm{Ni}^{2+}$ redox couples, directly affect the change from the semiconductor-like to metallic conducting behavior, indicating that $\mathrm{Ni}$ doping into Fe-site causes the $3 \mathrm{~d}$ electron delocalized $[23,34]$. Therefore, LSFN sample presents improved conductivity and is superior to both $\mathrm{Sr}_{3} \mathrm{Fe}_{2} \mathrm{O}_{7-\delta}$ and $\mathrm{La}_{3} \mathrm{Ni}_{2} \mathrm{O}_{7-\delta}$.

Before the electrochemical performance of LSFN single-phase and composite cathode for anode supported PCFCs was measured, the chemical compatibility behavior of LSFN-BZCY mixture was evaluated. LSFN-BZCY mixture with the same mass was calcined in air at $800-1100{ }^{\circ} \mathrm{C}$ for $10 \mathrm{~h}$. There is no reaction between LSFN and BZCY before $1000{ }^{\circ} \mathrm{C}$ as shown in Fig. 4. Although a small amount of $(\mathrm{BaSr}) \mathrm{FeO}_{3-\delta}$ was observed, the vast majority of the LSFN-BZCY composite was very stable after calcined at $1100{ }^{\circ} \mathrm{C}$. Meanwhile, $(\mathrm{BaSr}) \mathrm{FeO}_{3-\delta}$-based cathode owns high catalytic activity and exhibits excellent electrochemical performance $\left(696 \mathrm{~mW} \cdot \mathrm{cm}^{-2}\right.$ at $700{ }^{\circ} \mathrm{C}$ [36]). Therefore, anode supported PCFCs based on LSFN single-phase and composite cathode have been measured from 650 to $500{ }^{\circ} \mathrm{C}$, and $I$ (current density) $-V$ (voltage) $-P$ (power density) curves are given in Fig. 5. The open-circuit voltage values of LSFN and LSFN-BZCY at $650{ }^{\circ} \mathrm{C}$ are 1.02 and $1.04 \mathrm{~V}$, respectively, indicating the highly dense microstructure of BZCY electrolyte. The maximum power densities of LSFN single-phase cathode are $348.0,219.6,136.2$, and $71.7 \mathrm{~mW} \cdot \mathrm{cm}^{-2}$ at $650,600,550$, and $500{ }^{\circ} \mathrm{C}$, respectively. In order to

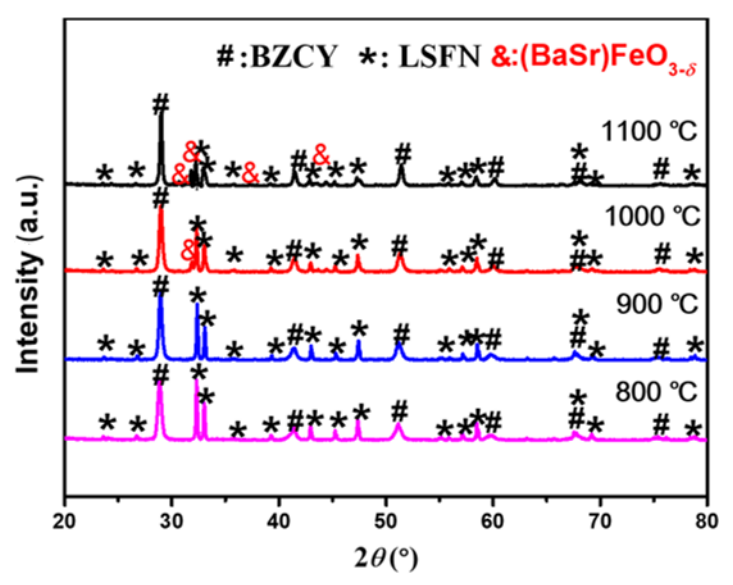

Fig. 4 XRD patterns of LSFN-BZCY mixture calcined at $800-1100{ }^{\circ} \mathrm{C}$ for $10 \mathrm{~h}$. 

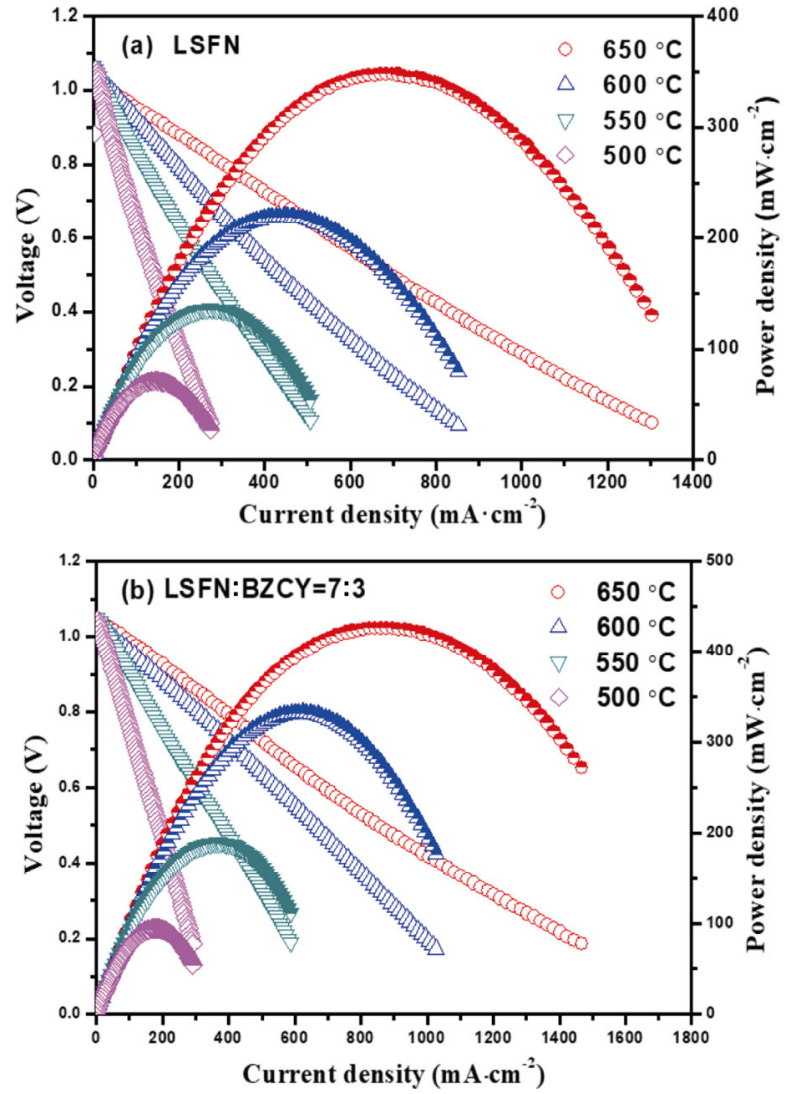

Fig. 5 (a) $I-V-P$ curves of anode supported PCFCs with LSFN single-phase cathode and (b) LSFN-BZCY composite cathode measured from 650 to $500{ }^{\circ} \mathrm{C}$.

determine the cell performance of the optimal mixing ratio of $\mathrm{LSFN}$ and $\mathrm{BZCY}$, the detailed $I-V-P$ curves are shown in Figs. S1-S3 in the Electronic Supplementary Material (ESM). Considering the same single cell structure and the same fabrication technology, the performance of single cell is directly attributed to the electrochemical behaviors of cathodes. This result indicates that the single cell using LSFN-BZCY (7:3) composite cathode as cathode exhibits a better performance. Obviously, LSFN-BZCY composite cathode exhibits much higher performance than Co-doped $\mathrm{La}_{3} \mathrm{Ni}_{2} \mathrm{O}_{7-\delta}\left(398 \mathrm{~mW} \cdot \mathrm{cm}^{-2}\right.$ [29]), but is still lower than $\mathrm{Sr}_{3} \mathrm{Fe}_{2} \mathrm{O}_{7-\delta}-5 \mathrm{wt} \% \mathrm{BZCY}$ composite cathode $\left(583 \mathrm{~mW} \cdot \mathrm{cm}^{-2}\right.$ [21]).

To evaluate the catalytic performance of LSFN-BZCY composite cathode for oxygen reduction reactions, electrochemical impedance spectroscopy (EIS) measurements were used to perform anode supported PCFCs under open-circuit conditions as shown in Fig. 6(a). Electrode polarization resistance $\left(R_{\mathrm{p}}\right)$ and the ohmic resistance $\left(R_{\mathrm{o}}\right)$ can be calculated from the impedance as well as the total resistance $\left(R_{\mathrm{t}}\right)$, and then presented
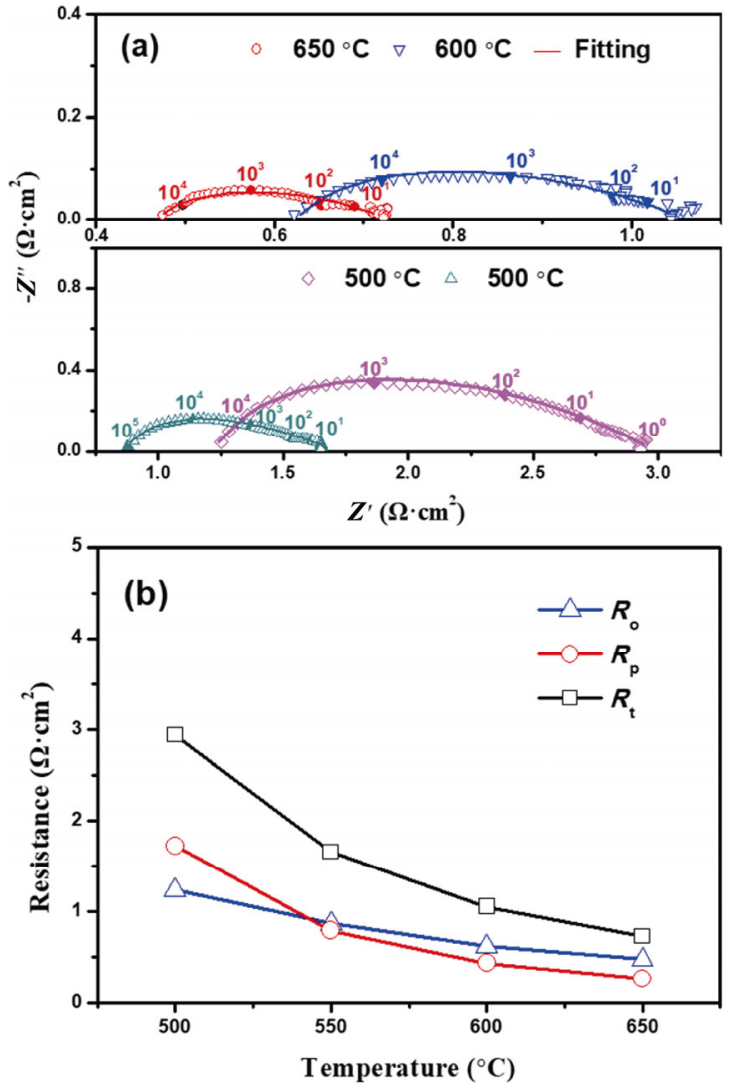

Fig. 6 (a) Impedance spectra for anode supported PCFCs with LSFN-BZCY composite cathode measured under open-circuit conditions from 650 to $500{ }^{\circ} \mathrm{C}$, and (b) the temperature dependence of electrode interfacial polarization resistance $\left(R_{\mathrm{p}}\right)$, ohmic resistance $\left(R_{\mathrm{o}}\right)$, and total resistance $\left(R_{\mathrm{t}}\right)$.

in Fig. 6(b). Temperature has a significant effect on $R_{\mathrm{p}}$ and $R_{\mathrm{o}}$ at the working temperatures, and the $R_{\mathrm{p}}$ value increased from 0.26 to $1.72 \Omega \cdot \mathrm{cm}^{2}$ with reducing the temperature, while corresponding $R_{\mathrm{o}}$ only changes from 0.47 to $1.23 \Omega \cdot \mathrm{cm}^{2}$, indicating that the $R_{\mathrm{p}}$ is the rate-limiting step for PCFCs at low temperatures. LSFN-BZCY composite cathode exhibits low $R_{\mathrm{p}}$ than Co-doped $\mathrm{La}_{3} \mathrm{Ni}_{2} \mathrm{O}_{7-\delta}\left(7.6 \Omega \cdot \mathrm{cm}^{2}\right.$ [29]), but much larger than $\mathrm{Sr}_{3} \mathrm{Fe}_{2} \mathrm{O}_{7-\delta}-5 \mathrm{wt} \% \mathrm{BZCY}$ composite cathode $\left(0.15 \Omega \cdot \mathrm{cm}^{2}[21]\right)$.

As to further detailly investigate the electrode polarization process of anode supported PCFCs with LSFN composite cathode under open circuit voltage (OCV) conditions, the impedance spectrum analysis using the DRT method can be characterized as the peaks in the $F(\tau)$ vs. $-\log _{10}(2 \pi \tau)$ curves as follows [37-40]:

$$
\begin{aligned}
F(\tau) & =\tau G(\tau) \ln (10) \\
& =\frac{-\ln (10)}{\pi}\left[Z^{\prime \prime}\left(\mathrm{e}^{-\ln \tau+\frac{\mathrm{j} \pi}{2}}\right)+Z^{\prime \prime}\left(\mathrm{e}^{-\ln \tau-\frac{\mathrm{j} \pi}{2}}\right)\right]
\end{aligned}
$$


where $Z^{\prime \prime}$ refers to the imaginary part of $Z$; $\tau$ is the relaxation time related to the frequency $f$ according to $\tau=1 / 2 \pi f$. As shown in Fig. 7(a), the calculated DRT plots exhibit several polarization processes. It clearly can be seen that there exist three (P1, P2, and P3) main peaks at different operation temperatures, suggesting there are three rate-limiting steps. Meanwhile, all the peaks shift to high frequencies with reducing the temperatures, suggesting the charge transfer with electron and oxygen-ion at reduced temperatures becomes more difficult at the electrode-electrolyte interfaces. Simulated resistances corresponded to $\mathrm{P} 1, \mathrm{P} 2$, and $\mathrm{P} 3$ are presented in Figs. 7(b) and 7(c). P1 observed at the high frequency decreases with the increasing temperature, and therefore $\mathrm{P} 1$ is considered to be proton incorporation and diffusion at cathode-electrolyte interface $[38,39]$. As can be seen from Fig. 7(b), the proportion of P1 is much larger than those of $\mathrm{P} 2$ and $\mathrm{P} 3$, indicating that $\mathrm{P} 1$ is the rate-limiting step for the reaction. The DRT result of LSFN at $650{ }^{\circ} \mathrm{C}$ as a comparison is shown in Fig. S4 in the ESM. It can be seen that LSFN also has P1 peak concerning proton transmission with the proton conductivity of LSFN. However, through the analysis at the same temperature, the proportion of $\mathrm{P} 1$ in the results of composite BZCY is significantly higher than that of non-composite BZCY. Since LSFN single-phase cathode has ignorable proton conductivity, the mixure of BZCY can dramatically improve the proton conducting behavior. $\mathrm{P} 2$ is the process of $\mathrm{H}_{2}$ adsorption, dissociation, and proton formation at anode, and the proportion of $\mathrm{P} 2$ is almost the same as temperature reduced. Certainly, P3 also decreases with the increasing temperature and locates at the low frequencies. Therefore, P3 is supposed to oxygen dissociation, adsorption, and diffusion in cathode with low proportion of about $19 \%$ at $500{ }^{\circ} \mathrm{C}$ owing to excellent conductivity of LSFN.

Figure 8 shows the long-term stability test of LSFN composite cathode with a $500 \mathrm{~mA} \cdot \mathrm{cm}^{-2}$ discharge current density at $650{ }^{\circ} \mathrm{C}$ in humidified $\mathrm{H}_{2}$ fuel. The output voltages varied with test time were recorded, and the results indicated that the voltage remained a stable value at $0.73 \mathrm{~V}$ within $220 \mathrm{~h}$ test. Figure 9(a) shows cross-sectional images of anode supported PFCFs with LSFN-BZCY cathode after long-term testing. The $30 \mu \mathrm{m}$-thickness proton BZCY electrolyte is dense enough and adheres well with LSFN-BZCY cathode under the cover of silver, preventing the gas leakage and ensuring efficient proton transmission.
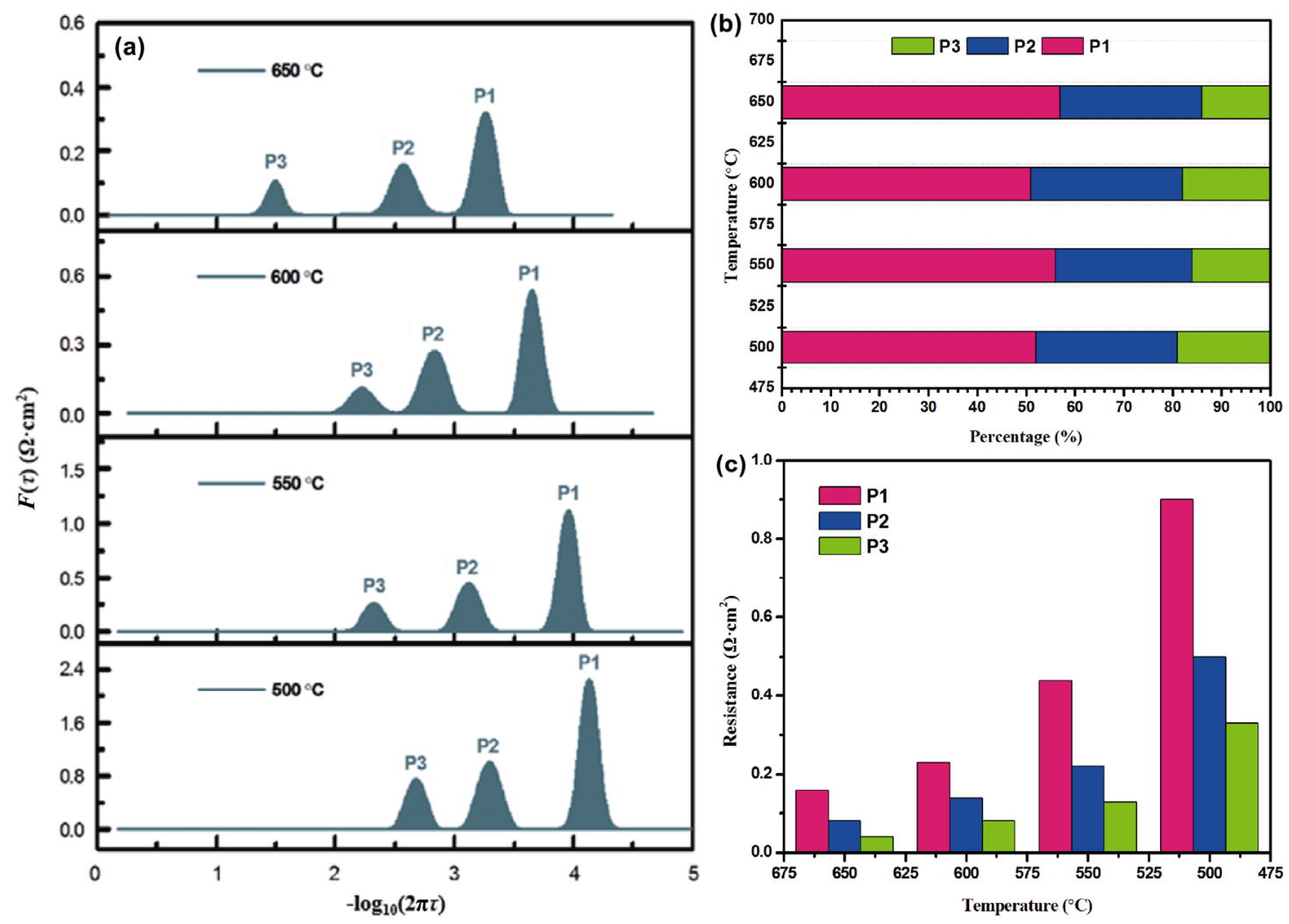

Fig. 7 (a) DRT analysis results of the impedance spectra under open-circuit conditions from 650 to $500{ }^{\circ} \mathrm{C}$, and (b, c) simulated resistances of $\mathrm{P} 1, \mathrm{P} 2$, and $\mathrm{P} 3$ corresponding to each fitted peak. 


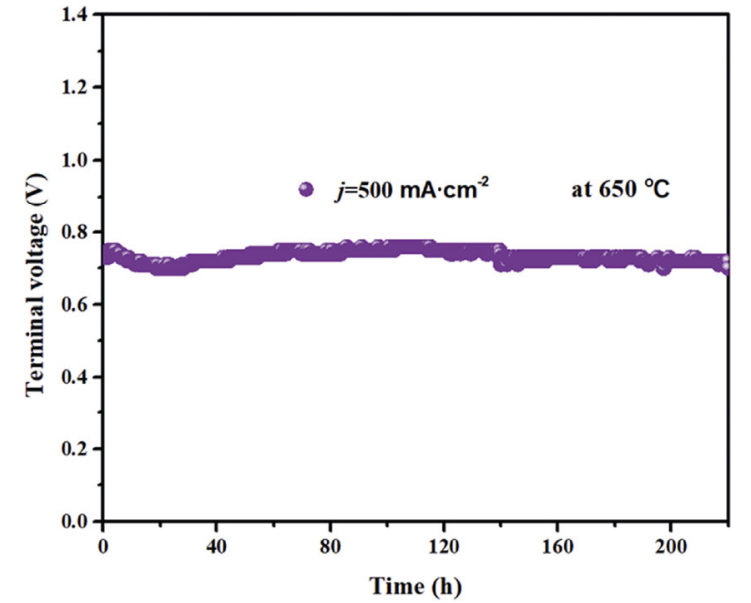

Fig. 8 Long-term stability of anode supported PCFCs with LSFN-BZCY composite cathode with the applied discharge current density of $500 \mathrm{~mA} \cdot \mathrm{cm}^{-2}$ at $650{ }^{\circ} \mathrm{C}$.
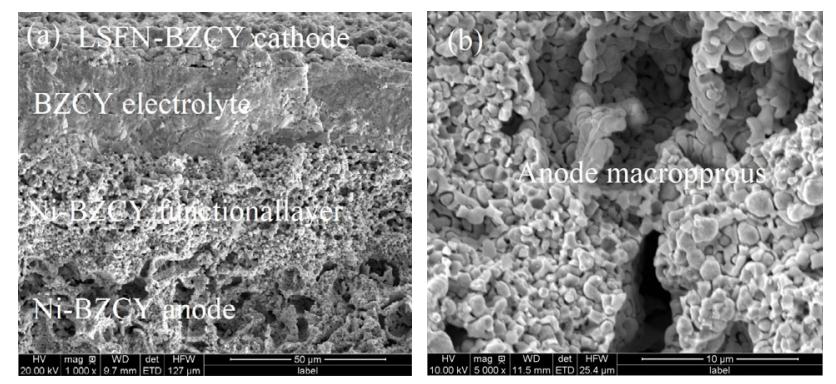

Fig. 9 SEM images of anode supported PCFCs with LSFN-BZCY cathode: (a) cross-section and (b) Ni-BZCY anode substrate.

Besides, there are many micropores at the approximate $35 \mu \mathrm{m}$-thick anode functional layer from the reduction of $\mathrm{NiO}$ and macroporous at anode substrate as shown in Fig. 9(b), leading to a better interfacial contact between anode substrate and electrolyte. Preliminary results demonstrated that new two-layer RP structure LSFN must be a promising cathode candidate for PCFCs, and catalytic activity and proton conductivity of LSFN single-phase cathode can be further enhanced by incorporation with BZCY.

\section{Conclusions}

In this work, we successfully synthesized two-layer RP oxide LSFN and then it was evaluated as the active single-phase and composite cathode for PCFCs. LSFN with the tetragonal symmetrical structure $(I 4 / \mathrm{mmm})$ is confirmed by the XRD Rietveld refinement. Furthermore, the XPS results obviously prove the co-existence of $\mathrm{Fe}^{3+} / \mathrm{Fe}^{4+}$ and $\mathrm{Ni}^{3+} / \mathrm{Ni}^{2+}$ couples in the combination of two RP phase oxides of $\mathrm{Sr}_{3} \mathrm{Fe}_{2} \mathrm{O}_{7-\delta}$ and $\mathrm{La}_{3} \mathrm{Ni}_{2} \mathrm{O}_{7-\delta}$, and directly affect the change from the semiconductor-like to metallic conducting behavior confirmed by the conductivity measurement. Importantly, anode supported PCFCs using LSFN-BZCY cathode achieved maximum power densities of $426.0,332.3,188.8$, and $94.5 \mathrm{~mW} \cdot \mathrm{cm}^{-2}$ from 650 to $500{ }^{\circ} \mathrm{C}$, with corresponding $R_{\mathrm{p}}$ of 0.29 , $0.43,0.79$, and $1.72 \Omega \cdot \mathrm{cm}^{2}$, respectively. The electrode polarization processes were further analyzed using the DRT function, and thus three polarization peaks ( $\mathrm{P} 1$, $\mathrm{P} 2$, and P3) observed in DRT curves shifted to the right at high frequencies with decreasing the temperature, suggesting that the charge transfer at the electrodeelectrolyte interfaces becomes more difficult at reduced temperatures. Preliminary results demonstrated two-layer RP structured LSFN can be a promising cathode candidate for PCFCs.

\section{Acknowledgements}

This work was financially supported by the Fundamental Research Funds for the Central Universities (No. 2019GF10).

\section{Electronic Supplementary Material}

Supplementary material is available in the online version of this article at https://doi.org/10.1007/s40145-021-0488-8.

\section{References}

[1] Radenahmad N, Afif A, Petra PI, et al. Proton-conducting electrolytes for direct methanol and direct urea fuel cells-A state-of-the-art review. Renew Sustain Energy Rev 2016, 57 : 1347-1358.

[2] Duan CC, Kee RJ, Zhu HY, et al. Highly durable, coking and sulfur tolerant, fuel-flexible protonic ceramic fuel cells. Nature 2018, 557: 217-222.

[3] Bonanos N, Huijser A, Poulsen FW. H/D isotope effects in high temperature proton conductors. Solid State Ion 2015, 275: 9-13.

[4] Wang XX, Wei KW, Yan SL, et al. Efficient and stable conversion of oxygen-bearing low-concentration coal mine methane by the electrochemical catalysis of SOFC anode: From pollutant to clean energy. Appl Catal B: Environ 2020, 268: 118413.

[5] Yang L, Zuo CD, Wang SZ, et al. A novel composite cathode for low-temperature SOFCs based on oxide proton conductors. Adv Mater 2008, 20: 3280-3283.

[6] Yang Y, Bao H, Ni H, et al. A novel facile strategy to suppress $\mathrm{Sr}$ segregation for high-entropy stabilized 
$\mathrm{La}_{0.8} \mathrm{Sr}_{0.2} \mathrm{MnO}_{3-\delta}$ cathode. J Power Sources 2021, 482: 228959.

[7] Shao ZP, Haile SM. A high-performance cathode for the next generation of solid-oxide fuel cells. Nature 2004, 431: 170-173.

[8] Tarutin AP, Lyagaeva JG, Medvedev DA, et al. Recent advances in layered $\mathrm{Ln}_{2} \mathrm{NiO}_{4+\delta}$ nickelates: Fundamentals and prospects of their applications in protonic ceramic fuel and electrolysis cells. J Mater Chem A 2021, 9: 154-195.

[9] Dong FF, Chen DJ, Ran R, et al. A comparative study of $\mathrm{Sm}_{0.5} \mathrm{Sr}_{0.5} \mathrm{MO}_{3-\delta}(\mathrm{M}=\mathrm{Co}$ and $\mathrm{Mn})$ as oxygen reduction electrodes for solid oxide fuel cells. Int J Hydrog Energy 2012, 37: 4377-4387.

[10] Nie LF, Liu MF, Zhang YJ, et al. $\mathrm{La}_{0.6} \mathrm{Sr}_{0.4} \mathrm{Co}_{0.2} \mathrm{Fe}_{0.8} \mathrm{O}_{3-\delta}$ cathodes infiltrated with samarium-doped cerium oxide for solid oxide fuel cells. J Power Sources 2010, 195: 4704-4708.

[11] Zhou W, Shao ZP, Ran R, et al. A novel efficient oxide electrode for electrocatalytic oxygen reduction at 400-600 'C. Chem Commun 2008: 5791-5793.

[12] Leng YJ, Chan SH, Liu QL. Development of LSCF-GDC composite cathodes for low-temperature solid oxide fuel cells with thin film GDC electrolyte. Int J Hydrog Energy 2008, 33: 3808-3817.

[13] Xia CR, Rauch W, Chen FL, et al. $\mathrm{Sm}_{0.5} \mathrm{Sr}_{0.5} \mathrm{CoO}_{3}$ cathodes for low-temperature SOFCs. Solid State Ion 2002, 149: $11-19$.

[14] Xu X, Xu YS, Ma JM, et al. Tailoring electronic structure of perovskite cathode for proton-conducting solid oxide fuel cells with high performance. J Power Sources 2021, 489: 229486.

[15] Nirala G, Yadav D, Upadhyay S. Ruddlesden-Popper phase $\mathrm{A}_{2} \mathrm{BO}_{4}$ oxides: Recent studies on structure, electrical, dielectric, and optical properties. $J$ Adv Ceram 2020, 9: 129-148.

[16] Beppu K, Hosokawa S, Teramura K, et al. Oxygen storage capacity of $\mathrm{Sr}_{3} \mathrm{Fe}_{2} \mathrm{O}_{7-\delta}$ having high structural stability. $J$ Mater Chem A 2015, 3: 13540-13545.

[17] Yashima M, Enoki M, Wakita T, et al. Structural disorder and diffusional pathway of oxide ions in a doped $\mathrm{Pr}_{2} \mathrm{NiO}_{4}$-based mixed conductor. J Am Chem Soc 2008, 130: 2762-2763.

[18] Tarancón A, Skinner SJ, Chater RJ, et al. Layered perovskites as promising cathodes for intermediate temperature solid oxide fuel cells. J Mater Chem 2007, 17: 3175-3181.

[19] Patrakeev MV, Leonidov IA, Kozhevnikov VL, et al. Ion-electron transport in strontium ferrites: Relationships with structural features and stability. Solid State Sci 2004, 6: 907-913.

[20] Ling Y, Wang F, Budiman RA, et al. Oxygen nonstoichiometry, the defect equilibrium model and thermodynamic quantities of the Ruddlesden-Popper oxide $\mathrm{Sr}_{3} \mathrm{Fe}_{2} \mathrm{O}_{7-\delta}$. Phys Chem Chem Phys 2015, 17: 7489-7497.

[21] Wang ZQ, Yang WQ, Shafi SP, et al. A high performance cathode for proton conducting solid oxide fuel cells. $J$ Mater Chem A 2015, 3: 8405-8412.

[22] Ling YH, Guo TM, Zhang XZ, et al. Evaluation of electrical conductivity and oxygen diffusivity of the typical Ruddlesden-Popper oxide $\mathrm{Sr}_{3} \mathrm{Fe}_{2} \mathrm{O}_{7-\delta}$. Ceram Int 2017, 43: 16264-16269.

[23] Mogni L, Prado F, Ascolani H, et al. Synthesis, crystal chemistry and physical properties of the Ruddlesden-Popper phases $\mathrm{Sr}_{3} \mathrm{Fe}_{2-x} \mathrm{Ni}_{x} \mathrm{O}_{7-\delta}(0 \leqslant x \leqslant 1.0)$. J Solid State Chem 2005, 178: 1559-1568.

[24] Mogni L, Prado F, Caneiro A. Defect structure and electrical conductivity of the Ruddlesden-Popper phases $\mathrm{Sr}_{3} \mathrm{FeMO}_{6+\delta}(\mathrm{M}=\mathrm{Co}$, Ni). Chem Mater 2006, 18: 4163-4170.

[25] Ling YH, Wang F, Okamoto $\mathrm{Y}$, et al. Oxygen nonstoichiometry and thermodynamic quantities in the Ruddlesden-Popper oxides $\mathrm{La}_{x} \mathrm{Sr}_{3-x} \mathrm{Fe}_{2} \mathrm{O}_{7-\delta}$. Solid State Ion 2016, 288: 298-302.

[26] Ling YH, Wang F, Okamoto Y, et al. Oxygen nonstoichiometry and thermodynamic explanation of large oxygen-deficient ruddlesden-popper oxides $\mathrm{La}_{x} \mathrm{Sr}_{3-x} \mathrm{Fe}_{2} \mathrm{O}_{7-\delta}$. J Am Ceram Soc 2016, 99: 3792-3801.

[27] Yoo S, Choi S, Shin J, et al. Electrical properties, thermodynamic behavior, and defect analysis of $\mathrm{La}_{n+1} \mathrm{Ni}_{n} \mathrm{O}_{3 n+1+d}$ infiltrated into YSZ scaffolds as cathodes for intermediate-temperature SOFCs. RSC Adv 2012, 2: 4648-4655.

[28] Amow G, Davidson IJ, Skinner SJ. A comparative study of the Ruddlesden-Popper series, $\mathrm{La}_{n+1} \mathrm{Ni}_{n} \mathrm{O}_{3 n+1}(n=1,2$ and 3 ), for solid-oxide fuel-cell cathode applications. Solid State Ion 2006, 177: 1205-1210.

[29] Chen ZZ, Wang JL, Huan DM, et al. Tailoring the activity via cobalt doping of a two-layer Ruddlesden-Popper phase cathode for intermediate temperature solid oxide fuel cells. J Power Sources 2017, 371: 41-47.

[30] Yang Y, Chen YH, Tian D, et al. A new A-site excessive strategy to improve performance of layered perovskite cathode for intermediate-temperature solid oxide fuel cells. Electrochimica Acta 2017, 231: 686-693.

[31] Velázquez-Palenzuela A, Zhang L, Wang LC, et al. Carbon-supported $\mathrm{Fe}-\mathrm{N}_{x}$ catalysts synthesized by pyrolysis of the $\mathrm{Fe}(\mathrm{II})-2,3,5,6$-tetra(2-pyridyl)pyrazine complex: Structure, electrochemical properties, and oxygen reduction reaction activity. J Phys Chem C 2011, 115: 12929-12940.

[32] Xiao GL, Liu Q, Wang SW, et al. Synthesis and characterization of Mo-doped $\mathrm{SrFeO}_{3-\delta}$ as cathode materials for solid oxide fuel cells. J Power Sources 2012, 202: 63-69.

[33] Dai NN, Feng J, Wang ZH, et al. Synthesis and characterization of B-site Ni-doped perovskites $\mathrm{Sr}_{2} \mathrm{Fe}_{1.5-x} \mathrm{Ni}_{x} \mathrm{Mo}_{0.5} \mathrm{O}_{6-\delta}(x=0,0.05,0.1,0.2,0.4)$ as cathodes for SOFCs. $J$ Mater Chem A 2013, 1: 14147-14153.

[34] Kang HW, Lim SN, Park SB. Co-doping schemes to enhance $\mathrm{H}_{2}$ evolution under visible light irradiation over $\mathrm{SrTiO}_{3}: \mathrm{Ni} / \mathrm{M}(\mathrm{M}=\mathrm{La}$ or $\mathrm{Ta})$ prepared by spray pyrolysis. 
Int J Hydrog Energy 2012, 37: 5540-5549.

[35] Lu YX, Jiang Y, Yang Z, et al. Polymer-assisted synthesis of $\mathrm{LiNi}_{2 / 3} \mathrm{Mn}_{1 / 3} \mathrm{O}_{2}$ cathode material with enhanced electrochemical performance. J Alloys Compd 2013, 559: 203-208.

[36] Sun WP, Shi Z, Fang SM, et al. A high performance $\mathrm{BaZr}_{0.1} \mathrm{Ce}_{0.7} \mathrm{Y}_{0.2} \mathrm{O}_{3-\delta}$-based solid oxide fuel cell with a cobalt-free $\quad \mathrm{Ba}_{0.5} \mathrm{Sr}_{0.5} \mathrm{FeO}_{3-\delta}-\mathrm{Ce}_{0.8} \mathrm{Sm}_{0.2} \mathrm{O}_{2-\delta} \quad$ composite cathode. Int J Hydrog Energy 2010, 35: 7925-7929.

[37] Fuoss RM, Kirkwood JG. Electrical properties of solids. VIII. Dipole moments in polyvinyl chloride-diphenyl systems. J Am Chem Soc 1941, 63: 385-394.

[38] Shi N, Su F, Huan DM, et al. Performance and DRT analysis of P-SOFCs fabricated using new phase inversion combined tape casting technology. J Mater Chem A 2017, 5: 19664-19671.

[39] Xu H, Dang Z. Numerical investigation of coupled mass transport and electrochemical reactions in porous SOFC anode microstructure. Int $J$ Heat Mass Transf 2017, 109: 1252-1260.
[40] Wang X, Ma Z, Zhang T, et al. Charge-transfer modeling and polarization DRT analysis of proton ceramics fuel cells based on mixed conductive electrolyte with the modified anode-electrolyte interface. ACS Appl Mater Inter 2018, 10: 35047-35059.

Open Access This article is licensed under a Creative Commons Attribution 4.0 International License, which permits use, sharing, adaptation, distribution and reproduction in any medium or format, as long as you give appropriate credit to the original author(s) and the source, provide a link to the Creative Commons licence, and indicate if changes were made.

The images or other third party material in this article are included in the article's Creative Commons licence, unless indicated otherwise in a credit line to the material. If material is not included in the article's Creative Commons licence and your intended use is not permitted by statutory regulation or exceeds the permitted use, you will need to obtain permission directly from the copyright holder.

To view a copy of this licence, visit http://creativecommons. org/licenses/by/4.0/. 